\title{
PENGARUH BRAND PERFORMANCE THE JAYAKARTA BANDUNG BOUTIQUE SUITE HOTEL \& SPA TERHADAP KEPUTUSAN TAMU UNTUK MENGINAP
}

\author{
Indah Nur Agustiani \\ Anthony Barbo \\ Manajemen Pemasaran Pariwisata FPIPS UPI
}

\begin{abstract}
The impact of hotel industries which is developing the high competition of hotel industries. The level of room residential is the important thing to view that the number of the room is sold. The guest decision to stay is the most important thing to the hotel industries. With the guest decision to hotel, then the level of guest residential will increase which is the main target of hotel industries. Therefore the Jayakarta Bandung Boutique Suite Hotel \& Spa wants the guest decision to be enhanced. The one of effort to increase the guest decision to stay is maximize the brand performance which is do it by The Jayakarta Bandung Boutique Suite Hotel and Spa. The purpose of the study is to obtain findings the brand performance which has been done, the decision to stay in The Jayakarta Bandung Boutique Suite Hotel \& Spa and the influence of brand performance towards the decision to stay. Kevin L. Keller is the theory of brand performance which is used. While the theory of post-visit behavior using the theory of Kotler and Keller. The object of the study is the visitor who stay in The Jayakarta Bandung Boutique Suite Hotel \& Spa. This type of research is descriptive and verification, and the method used is explanatory survey stratified random sampling, hence obtained a population of 100 respondent. The data analysis technique and hypothesis test used is the path analysis (path analysis). The results show interesting findings, that the brand performace give the significant influence towards to the stay decision which consist of product, brand, reservation channel, lenght of stay, the number of room reservation and the payment method. The biggest impact of brand performance towards the stay decision is obtained from Product Reliability, Durability and Service Ability and the smallest influence is obtained from Service Effectiveness, Efficiency, And Empathy. As for suggestions for the company in improving the decision to stay at The Jayakarta Bandung Suite Boutique Hotel \& Spa is a brand performance through the development of a more exciting, creative, innovative, effective and efficient.
\end{abstract}

Keywords: Brand Performance, Decision to Stay, Product Reliability, Durability and Service Ability, Service Effectiveness, Efficiency, Empathy

\section{PENDAHULUAN}

\subsection{Latar Belakang Penelitian}

Industri pariwisata pada saat ini merupakan salah satu industri yang menjadi penggerak perekonomian di sebagian besar negara di dunia. Industri pariwisata sebagai salah satu sektor bisnis hospitality yang merupakan suatu bisnis besar dalam penyediaan barang dan jasa untuk wisatawan dan menyangkut setiap pengeluaran wisatawan dalam perjalanannya. Pariwisata merupakan bagian yang tidak terpisahkan dari kehidupan manusia terutama menyangkut kegiatan sosial dan ekonomi.

Tingkat penghunian kamar merupakan suatu keadaan sampai sejauh mana jumlah kamar pada suatu hotel terjual, jika dibandingkan dengan seluruh jumlah kamar yang mampu untuk dijual. Oleh karena itu, keputusan menginap tamu merupakan hal terpenting bagi sebuah industri hotel. Berikut ini data mengenai tingkat hunian The Jayakarta Bandung Boutique Suite Hotel \& Spa dari tahun 2008 sampai 2010.

TABEL 1.1

DATA TINGKAT OCCUPANCY THE JAYAKARTA BANDUNG BOUTIQUE SUITE HOTEL \& SPA

\begin{tabular}{|l|l|l|}
\hline Tahun & $\begin{array}{c}\text { Occupancy } \\
(\%)\end{array}$ & $\begin{array}{c}\text { Jumlah } \\
\text { Occupancy }\end{array}$ \\
\hline 2008 & $57.90 \%$ & 44.652 \\
\hline 2009 & $59.49 \%$ & 45.702 \\
\hline 2010 & $64.34 \%$ & 49.346 \\
\hline
\end{tabular}


Sumber : sales and marketing Hotel The Jayakarta Bandung (2011)

Berdasarkan Tabel 1.1 dapat dilihat bahwa pada tahun 2008 sampai 2010 The Jayakarta Bandung Boutique Suite Hotel \& Spa memiliki kenaikan tingkat hunian kamar (occupancy) yang dimana pada tahun 2009 mengalami kenaikan $1.59 \%$ dari tahun 2008, dan untuk tahun 2010 mengalami kenaikan sebesar $4.85 \%$ dari tahun 2009. Tingkat hunian kamar (occupancy) yang terjadi pada tahun 2010 belum mampu mencapai target yang diinginkan manajemen yaitu $65 \%$ tingkat hunian kamar (occupancy).Berdasarkan latar belakang tersebut maka perlu dilakukan suatu penelitian mengenai "PENGARUH BRAND PERFORMANCE THE JAYAKARTA BANDUNG BOUTIQUE SUITE HOTEL \& SPA TERHADAP KEPUTUSAN TAMU UNTUK MENGINAP”.

\subsection{Rumusan Masalah}

Berdasarkan latar belakang penelitian di atas, maka dapat dirumuskan masalah penelitian sebagai berikut:

1. Bagaimana brand performance yang dilakukan di The Jayakarta Bandung Boutique Suite Hotel \& Spa.

2. Bagaimana keputusan tamu untuk menginap di The Jayakarta Bandung Boutique Suite Hotel \& Spa.

3. Bagaimana pengaruh brand performance terhadap keputusan tamu untuk menginap di The Jayakarta Bandung Boutique Suite Hotel \& Spa.

\subsection{Tujuan Penelitian}

Berdasarkan rumusan masalah, maka tujuan penelitian ini adalah untuk memperoleh hasil temuan mengenai :

1. Brand performance yang dilakukan di The Jayakarta Bandung Boutique Suite Hotel \& Spa.

2. Keputusan tamu untuk menginap di The Jayakarta Bandung Boutique Suite Hotel \&Spa.

3. Pengaruh brand performance terhadap keputusan tamu untuk menginap di The Jayakarta Bandung Boutique Suite Hotel \& Spa.

\subsection{Kegunaan Penelitian}

a. Kegunaan Teoritis
Hasil penelitian ini diharapkan akan memperluas wawasan kajian ilmu mengenai kepariwisataan, di jurusan Manajemen Pemasaran Pariwisata khususnya pada manajemen pemasaran hotel serta dalam mengembangkan kajian mengenai ilmu pemasaran khususnya yang memiliki keidentikan dengan teori Brand Performance terhadap penciptaan keputusan tamu untuk menginap pada The Jayakarta Bandung Boutique Suite Hotel \& Spa.

b. Kegunaan Praktis

Secara praktis hasil penelitian ini diharapkan dapat memberikan masukan bagi pihak manajemen The Jayakarta Bandung Boutique Suite Hotel \& Spa khususnya dalam upaya merespon tamu untuk membuat keputusan menginap di The Jayakarta Bandung Boutique Suite Hotel \& Spa melalui pengaruh brand performance. Dengan demikian, hal tersebut dapat dijadikan bahan informasi serta masukan bagi pihak hotel dalam upaya meningkatkan tingkat hunian kamar (occupancy) di The Jayakarta Bandung Boutique Suite Hotel \& Spa.

\section{KERANGKA PEMIKIRAN DAN HIPOTESIS}

\subsection{Kerangka Pemikiran}

Pemasaran pada dasarnya merupakan segala kegiatan yang menyangkut masalah penyaluran produk dari produsen ke konsumen dimana perusahaan suatu rencana dengan menentukan harga dan promosi yang diorientasikan pada pelanggan serta memperhatikan kebutuhan serta keinginan pelanggan secara memuaskan. Menurut Kotler dan Keller (2009:5) mengemukakan, pengertian pemasaran adalah sebuah proses kemasyarakatan di mana individu dan kelompok memperoleh apa yang mereka butuhkan dan inginkan dengan menciptakan, menawarkan, dan secara bebas mempertukarkan produk dan jasa yang bernilai dengan orang lain

Pemasaran menyebabkan pelanggan siap membeli sehingga hanyalah bagaimana membuat produknya tersedia. Sedangkan proses pemasaran terdiri dari analisa peluang pasar, meneliti dan memilih pasar sasaran, 
merancang strategi pemasaran, merancang program pemasaran, dan mengorganisir, melaksanakan serta mengawasi usaha pemasaran. Untuk mencapai suatu pemasaran yang unggul, diperlukan strategi pemasaran.

Strategi pemasaran dalam konteks strategi perusahaan tidak dapat berdiri sendiri. Strategi pemasaran merupakan Komponen yang tidak terpisahkan dari strategi wilayah fungsional dari perusahaan, misalnya pemasaran, keuangan dan sumber daya manusia, desain dan diimplementasikan berbarengan dengan strategi lainnya. Strategi pemasaran menurut W.Y.Stanton (2005:45) adalah serangkaian tindakan terpadu menuju keunggulan kompetitif yang berkelanjutan.

Menurut Kotler dalam Abdul Majid (2008:57) strategi pemasaran adalah pengambilan keputusan-keputusan tentang biaya pemasaran, bauran pemasaran, alokasi pemasaran dalam hubungan dengan keadaan lingkungan yang diharapkan dan kondisi persaingan. Sebuah strategi pemasaran harus berpusat di sekitar konsep kunci bahwa kepuasan pelanggan adalah tujuan utama. Sebuah strategi pemasaran yang paling efektif ketika merupakan komponen integral dari strategi perusahaan, menentukan bagaimana organisasi berhasil akan terlibat pelanggan, prospek, dan pesaing dalam arena pasar. strategi perusahaan, misi perusahaan, dan tujuan perusahaan.

Menurut Hermawan Kertajaya (2005:13) dalam suatu strategi pemasaran diperlukan suatu alat yang dipakai untuk memasarkannya yang disebut Strategic Place Triangle yaitu : (1) Penetapan Positioning, upaya untuk membangun suatu posisi dibenak pelanggan. (2) Pengembangan Differentiation, upaya untuk membedakan diri melalui pemberian value proposition yang unik dan berbeda dari apa yang diberikan oleh daerah pesaing. (3) Membangun Brand. Membangun brand tidak lain adalah membangun awareness, asosiasi merek, persepsi kualitas, dan loyalitas merek.

Produk dan jasa yang didalamnya mengandung elemen merek yang kuat, sebagai suatu pembeda yang jelas, bernilai, dan berkesinambungan penting digunakan sebagai salah satu strategi pemasaran dalam menghadapi persaingan yang ketat. Oleh sebab itu, penempatan merek pada persepsi tamu dan seluruh stakeholder, berkontribusi besar terhadap kesuksesan sebuah organisasi atau perusahaan karena merek yang memiliki asosiasi positif mengandung value dan kekuatan, atau dianggap memiliki ekuitas merek (brand equity) yang tak ternilai.

Sebagai intangible asset perusahaan, merek mencerminkan keseluruhan persepsi tamu mengenai kinerja produk, merek dan maknanya, dan perusahaan yang diasosiasikan pada merek yang bersangkutan. Serangkaian aset dan liabilitas merek yang terkait dalam sebuah merek, nama dan simbolnya yang menambah atau mengurangi nilai yang diberikan suatu produk atau jasa kepada perusahaan dan/atau pelanggan perusahaan tersebut didefinisikan oleh Aaker dalam Kotler (2009:284) sebagai brand equity. Sementara itu, Keller (2008:48) menyatakan bahwa ekuitas merek adalah efek diferensial dari pengetahuan merek atau tanggapan konsumen terhadap pemasaran merek.

Kotler dan Armstrong (2008:350) juga menambahkan bahwa brand equity adalah nilai dari suatu merek menurut sejauh mana merek itu mempunyai loyalitas merek (brand loyalty) yang tinggi, kesadaran merek (brand awareness), kualitas yang diterima (perceived quality), asosiasi merek yang kuat serta asset lain seperti paten, merek dagang, dan hubungan saluran.

Manfaat yang akan diperoleh apabila perusahaan menempatkan strategi brand equity adalah sebagai sarana identifikasi untuk memudahkan proses pengidentifikasian produk maupun jasa, sebagai sarana menciptakan asosiasi dan makna unik yang membedakan produk dari pesaing, sebagai sumber keunggulan kompetitif serta sumber finansial di masa yang akan datang.

Menurut Aaker dalam Kotler (2009:284) model brand equity diformulasikan dari sudut pandang manajerial dan strategi korporat, meskipun landasan utamanya yakni perilaku konsumen. Aaker menjabarkan aset merek yang berkontribusi pada brand equity ke dalam tiga dimensi yakni: (1) brand awareness, (2) brand loyalty, dan (3) brand associations. Sementara itu, model Kotler (2009:287) dan Keller (2008:60) model brand equity yaitu : (1) brand salience, (2) brand performance, (3) brand imagery, (4) brand feelings, (5) brand judgement, dan (6) brand resonance.

Pada penelitian ini menggunakan brand performance dari Kotler (2009:287) dan Keller 
(2008:60) yang mempunyai definisi Brand Performance is "Describes how well the product or service meets customers more functional needs". Artinya bagaimana kemampuan produk dan jasa dalam memenuhi kebutuhan fungsional konsumen. Dengan pengukuran sebagai berikut:

Primary ingredients and supplementary features, pelanggan sering memiliki keyakinan tentang tingkat di mana bahan utama produk beroperasi (rendah, sedang, tinggi, atau sangat tinggi), dan khususnya untuk produk yang sudah diresmikan, fitur atau elemen sekunder yang melengkapi bahan ini bersifat primer. Beberapa atribut yang diperlukan untuk suatu produk untuk bekerja, sedangkan yang lain adalah fitur tambahan yang memungkinkan agar lebih fleksibel, dalam penggunaan pribadi. Tentu saja hal ini berbeda-beda menurut kategori produk atau jasa.

Product reliability, durability, and serviceability, Bagaimana tampilan kinerja pelanggan, hal ini terukur oleh reliabilitas konsistensi kinerja dari waktu ke waktu dan dari pembelian untuk membeli. Durabilitas adalah kehidupan ekonomi yang diharapkan produk, dan serviceabilitas kemudahan memperbaiki produk jika diperlukan. Dengan demikian, persepsi kinerja produk dipengaruhi oleh faktor-faktor seperti kecepatan, akurasi, perawatan dan pemasangan produk, bagaimana kecepatan, kesopanan, dan cara memberikan pertolongan kepada pelanggan dengan memperhatikan waktu dan kualitas.

Service effectiveness, efficiency, and emphaty, pelanggan sering memiliki kinerja asosiasi terkait dengan layanan. Layanan efektivitas mengukur seberapa baik merek ini memenuhi kebutuhan pelanggan dalam setiap layanan. Layanan efisiensi menggambarkan kecepatan dan respon pelayanan. Akhirnya, empati layanan sejauh mana penyedia layanan dilihat sebagai percaya, peduli, dan memiliki kepentingan pelanggan dalam pikiran.

Style and design, konsumen mungkin memiliki asosiasi dengan produk yang melampaui aspek fungsional untuk pertimbangan estetika lebih seperti ukuran, bentuk, bahan, dan warna yang terlibat. Dengan demikian, kinerja mungkin juga tergantung pada aspek sensori seperti bagaimana produk terlihat dan terasa, dan mungkin bahkan apa yang terdengar atau baunya seperti.
Price, kebijakan harga untuk merek tersebut dapat membuat asosiasi dalam benak konsumen tentang bagaimana relatif mahal (atau mahal) merek ini, dan apakah sering atau secara substansial diskon. Harga adalah asosiasi kinerja sangat penting karena konsumen dapat mengorganisir pengetahuan kategori produk mereka dalam hal tingkatan harga merek yang berbeda. yang sesuai dengan unsur-unsur yang diimplementasikan oleh The Jayakarta Bandung Boutique Suite Hotel \& Spa.

Menurut Zeithaml (2006:26) dalam jurnal brand performance: quality assurance in hospitality \& tourism mengemukakan bahwa penelitian yang secara langsung mempengaruhi kepuasan tamu hotel adalah bagaimana kualitas brand performance.

Keputusan menginap di Hotel mengadopsi dari satu teori yaitu keputusan pembelian. Menurut Kotler \& Keller (2009:226) mendefinisikan keputusan pembelian adalah tahap dalam proses pengambilan keputusan pembelian di mana konsumen benarbenar memilih tempat pembeliannya. Keputusan konsumen untuk memodifikasi, menunda, atau menghindari suatu keputusan pembelian sangat dipengaruhi oleh resiko yang dirasakan. karena memiliki ciri-ciri yang sama. Maka dalam penelitian ini ada enam keputusan yang dilakukan oleh konsumen, yaitu:

Pemilihan Produk, ialah tamu dapat mengambil keputusan untuk melakukan pembelian mengenai sebuah produk atau menggunakan uangnya untuk tujuan yang lain. Ukuranya adalah kualitas, variasi, penawaran, keunggulan, dan kestrategisan.

Pemilihan Merek, ialah tamu harus memutuskan merek mana yang akan mereka pilih. Setiap merek memiliki perbedaanperbedaan tersendiri. Dalam hal ini perusahaan harus mengetahui bagaimana tamu memilih sebuah produk. Ukurannya adalah citra, menginap, pengalaman.

Pemilihan Saluran Distribusi, ialah tamu harus mengambil keputusan tentang sarana mana yang akan digunakan. Setiap tamu berbeda-beda dalam hal menentukan dealer yang bisa dikarenakan faktor lokasi, harga yang murah, persediaan barang yang lengkap, kenyamanan berbelanja, keluasan tempat dan sebagainya. 
Waktu Pembelian, ialah keputusan tamu dalam pemilihan waktu menginap bisa berbeda-beda, misalnya ada yang membeli setiap hari, satu minggu sekali, satu bulan sekali dan mungkin satu tahun sekali. Ukurannya adalah waktu menginap.

Jumlah Pembelian, ialah tamu dapat mengambil keputusan tentang seberapa banyak produk yang akan dibelinya pada suatu saat. Menginap dilakukan mungkin lebih dari satu. Dalam hal ini perusahaan harus mempersiapkan banyaknya produk sesuai dengan keinginan yang berbeda-beda dari setiap pembeli. Ukurannya adalah alasan menginap.

Metode Pembayaran, ialah tamu dalam menginap suatu barang dan jasa pasti harus melakukan suatu pembayaran. Pada saat pembayaran inilah biasanya tamu ada yang melakukan pembayaran secara tunai maupun menggunakan kartu kredit. Ukurannya adalah alat pembayaran yang digunakan.

Keputusan menginap merupakan salah satu proses dari tahapan menginap tamu, yakni pada saat tamu benar-benar melakukan tindakan terhadap suatu produk. Salah satu langkah sebuah hotel untuk mendorong tamu dan menarik perhatiannya adalah dengan membangun posisi merek yang baik pada produknya. Untuk lebih jelasnya dapat dilihat pada Gambar 2.1 berikut: 


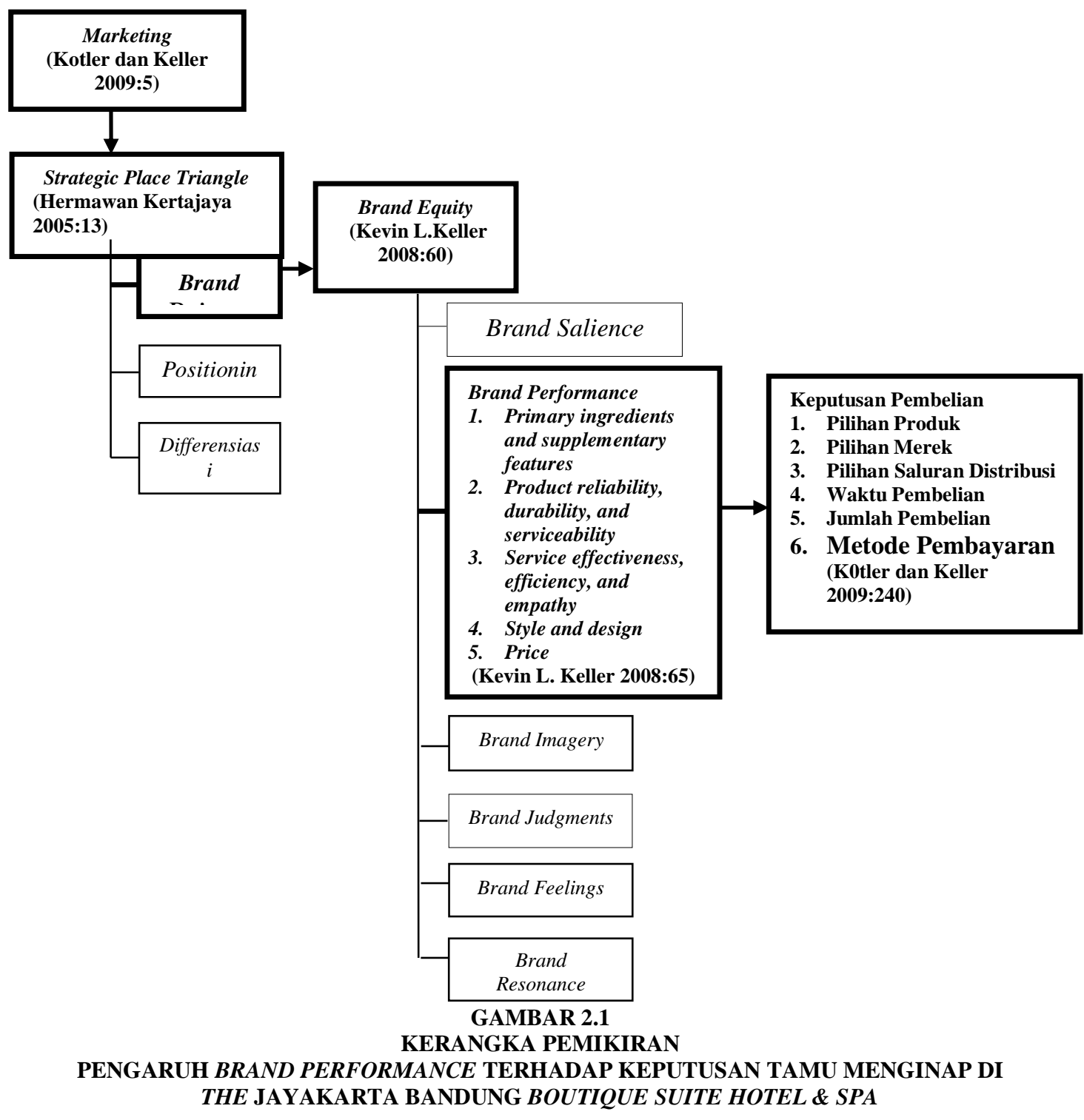




\subsection{Hipotesis Penelitian}

Menurut Sugiyono (2008:64) "hipotesis merupakan jawaban sementara terhadap rumusan masalah penelitian, dimana rumusan penelitian masalah telah dinyatakan dalam bentuk kalimat". Dikatakan sementara, karena jawaban yang diberikan baru didasarkan pada teori yang relevan, belum didasarkan pada fakta-fakta empiris yang diperoleh dari pengumpulan data.

Peneliti dalam menyusun hipotesis didukung oleh beberapa premis sebagai berikut:

1. Menurut Andrew G. Parsons dalam Journal of Product \& Brand Management (2008): Consumers tend to look for brands with greater perceived symbolic benefits when purchasing gifts.

2. Menurut Paul Marsden dalam Journal Marketing intelligence \& Planning (2008): Brands are actually positioned in the minds of consumers in terms of thei component memes, that is, their "genes of meaning".

3. Menurut Himawan W. dan AB. Susanto (2004): Memosisikan merek adalah bagian yang dominan dalam masalah merek dan merupakan sebuah proses dimana perusahaan menawarkan merek kepada konsumen, yang nantinya akan membangun persepsi konsumen dan sebagai faktor pendukung konsumen untuk membeli merek tersebut.

4. Menurut Zeithaml (2006:26) dalam jurnal brand performance: quality assurance in hospitality \& tourism mengemukakan bahwa penelitian yang secara langsung mempengaruhi kepuasan tamu hotel adalah bagaimana kinerja merek.

Berdasarkan premis di atas, maka hipotesis dalam penelitian ini adalah: Terdapat pengaruh yang signifikan antara brand performance The Jayakarta Bandung Boutique Suite Hotel \& Spa terhadap keputusan menginap. (didukung oleh premis 1, 2, 3, 4)

\section{OBJEK DAN METODE} PENELITIAN

\subsection{Objek Penelitian}

Penelitian ini dilakukan terhadap tamu yang menginap di The Jayakarta Bandung Boutique Suite Hotel \& Spa. Variabel bebas adalah brand performance $(X)$ yang memiliki yang memiliki lima dimensi yaitu Primary ingredients and supplementary features, Product reliability, durability, and serviceability, Service effectiveness, efficiency, and empathy, Style and design, dan Price, sedangkan variabel terikat adalah keputusan menginap. Unit analisis yang dijadikan responden dalam penelitian ini adalah tamu yang menginap di The Jayakarta Bandung Boutique Suite Hotel \& Spa. Penelitian ini dilakukan dalam kurun waktu kurang dari satu tahun, maka pendekatan yang digunakan menurut Sugiyono (2008:8) Cross sectional method.

\subsection{Metode Penelitian}

\subsubsection{Jenis Penelitian dan Metode yang Digunakan}

Di dalam penelitian ini digunakan jenis penelitian deskriptif dan verifikatif. Berdasarkan variable-variabel yang diteliti maka jenis penelitian ini adalah penelitian deskriptif dan verifikatif. Menurut Sugiyono (2008:35):

Penelitian deskriptif adalah penelitian yang dilakukan untuk mengetahui keberadaan variabel mandiri, baik satu variabel atau lebih variabel (variabel yang berdiri sendiri) tanpa membuat perbandingan dan atau mencari hubungan variabel satu sama lain.

Penelitian deskriptif di dalam penelitian ini bertujuan untuk memperoleh gambaran mengenai brand performance dan gambaran mengenai keputusan menginap dalam suatu industri perhotelan.

Menurut Sugiyono (2008:36), Penelitian verifikatif adalah penelitian yang membandingkan keberadaan satu variabel atau lebih pada dua atau lebih sampel yang berbeda, atau pada waktu yang berbeda. Sedangkan jenis penelitian verifikatif menguji kebenaran suatu hipotesis yang dilakukan melalui pengumpulan data di lapangan. Melalui penelitian verifikatif data-data dikumpulkan dari sumber data primer dan sekunder. Data primer diperoleh dengan menyebar kuesioner kepada sampel responden untuk memperoleh fakta yang relevan. Dalam penelitian ini di uji mengenai pengaruh brand performance terhadap keputusan menginap di The Jayakarta Bandung Boutique Suite Hotel \& Spa. 
Maka metode penelitian yang digunakan adalah metode deskriptif survey dan metode explanatory survey. Menurut Kerlinger dalam Sugiyono (2008: 7), yang dimaksud metode survei yaitu: Metode penelitian yang dilakukan pada populasi besar maupun kecil tapi data yang dipelajari adalah data dari sampel yang diambil dari populasi tersebut, sehingga ditemukan kejadian-kejadian relatif. Distribusi dan hubungan-hubungan antar variabel sosiologis maupun psikologis.

\subsection{Operasionalisasi Variabel}

Variabel yang diteliti dalam penelitian ini dioperasionalisasikan dalam dua variabel utama yaitu Variabel independen (bebas) adalah brand performance yang terdiri dari Primary ingredients and supplementary features, Product reliability, durability, and serviceability, Service effectiveness, efficiency, and empathy, Style and design, dan Price. Sedangkan variabel dependent (terikat) yaitu keputusan menginap yang terdiri dari pemilihan produk, pemilihan merek, pemilihan saluran reservasi, waktu menginap, jumlah pemesanan kamar, metode pembayaran.

Menurut Silalahi (2009:201) mengungkapkan bahwa, "Operasionalisasi variabel merupakan kegiatan mengurai variabel menjadi sejumlah variabel operasional atau variabel empiris (indikator, item) yang menunjuk langsung pada hal-hal yang dapat diamati atau diukur". Secara lebih rinci operasionalisasi variabel dalam penelitian ini disajikan dalam Tabel 3.1 sebagai berikut

TABEL 3.1

OPERASIONALISASI VARIABEL PENELITIAN






\begin{tabular}{|c|c|c|c|c|c|c|}
\hline Variabel & Sub Variabel & $\begin{array}{l}\text { Konsep } \\
\text { Variabel } \\
\text { dan Sub } \\
\text { Variabel }\end{array}$ & Indikator & Ukuran & Skala & $\begin{array}{c}\text { No } \\
\text { Item }\end{array}$ \\
\hline (1) & (2) & (3) & (4) & (5) & (6) & (7) \\
\hline & & & $\begin{array}{l}\text { - Keberagaman } \\
\text { tipe kamar Hotel } \\
\text { Jayakarta } \\
\text { - Tipe harga yang } \\
\text { ditawarkan } \\
\text { Hotel Jayakarta } \\
\\
\text { - Kinerja fasilitas } \\
\text { pendukung } \\
\text { Hotel }\end{array}$ & $\begin{array}{l}\text { - Tingkat } \\
\text { Keberagaman } \\
\text { tipe kamar } \\
\text { Hotel } \\
\text { - Tingkat Tipe } \\
\text { harga yang } \\
\text { ditawarkan } \\
\text { Hotel jayakarta } \\
\text { - Tingkat kinerja } \\
\text { fasilitas } \\
\text { pendukung }\end{array}$ & & $\begin{array}{l}\text { III.1.7 } \\
\text { III.1.8 }\end{array}$ \\
\hline & $\begin{array}{l}\text { Product } \\
\text { reliability, } \\
\text { durability } \\
\text { and } \\
\text { serviceability }\end{array}$ & $\begin{array}{l}\text { Reliabilitas } \\
\text { konsistensi } \\
\text { kinerja dari } \\
\text { waktu ke } \\
\text { waktu dan } \\
\text { dari } \\
\text { pembelian } \\
\text { untuk } \\
\text { membeli. } \\
\text { Durabilitas } \\
\text { adalah } \\
\text { kehidupan } \\
\text { ekonomi } \\
\text { yang } \\
\text { diharapkan } \\
\text { produk, dan } \\
\text { serviceabilita } \\
\text { s kemudahan } \\
\text { memperbaiki } \\
\text { produk jika } \\
\text { diperlukan } \\
\text { (Kevin } \\
\text { L.Keller } \\
\text { 2008) }\end{array}$ & $\begin{array}{l}\text { - Kestrategisan } \\
\text { lokasi Hotel } \\
\text { jayakarta } \\
\text { - Kemudahan } \\
\text { akses menuju } \\
\text { Hotel jayakarta } \\
\text { - Kecepatan } \\
\text { reservation } \\
\text { system } \\
\text { - Kemudahan } \\
\text { proses check-in } \\
\text { dan check-out } \\
\text { - Penyediaan } \\
\text { fasilitas kamar } \\
\text { dalam } \\
\text { memenuhi } \\
\text { kebutuhan tamu }\end{array}$ & $\begin{array}{l}\text { - Tingkat } \\
\text { kestrategisan } \\
\text { lokasi Hotel } \\
\text { Jayakarta } \\
\text { - Tingkat } \\
\text { kemudahan } \\
\text { akses menuju } \\
\text { hotel jayakarta } \\
\text { - Tingkat } \\
\text { kecepatan } \\
\text { reservation } \\
\text { system } \\
\text { - Tingkat } \\
\text { kemudahan } \\
\text { proses check-in } \\
\text { dan check-out } \\
\text { - Tingkat } \\
\text { penyediaan } \\
\text { fasilitas kamar } \\
\text { dalam } \\
\text { memenuhi } \\
\text { kebutuhan tamu } \\
\text { - Tingkat kinerja } \\
\text { fasilitas } \\
\text { pendukung } \\
\text { Hotel }\end{array}$ & $\begin{array}{l}\text { Hybrid } \\
\text { Ordin } \\
\text { aly } \\
\text { Scale }\end{array}$ & $\begin{array}{l}\text { III.1.1 } \\
1 \\
\text { III.1.1 } \\
2 \\
\text { III.1.1 } \\
3\end{array}$ \\
\hline
\end{tabular}




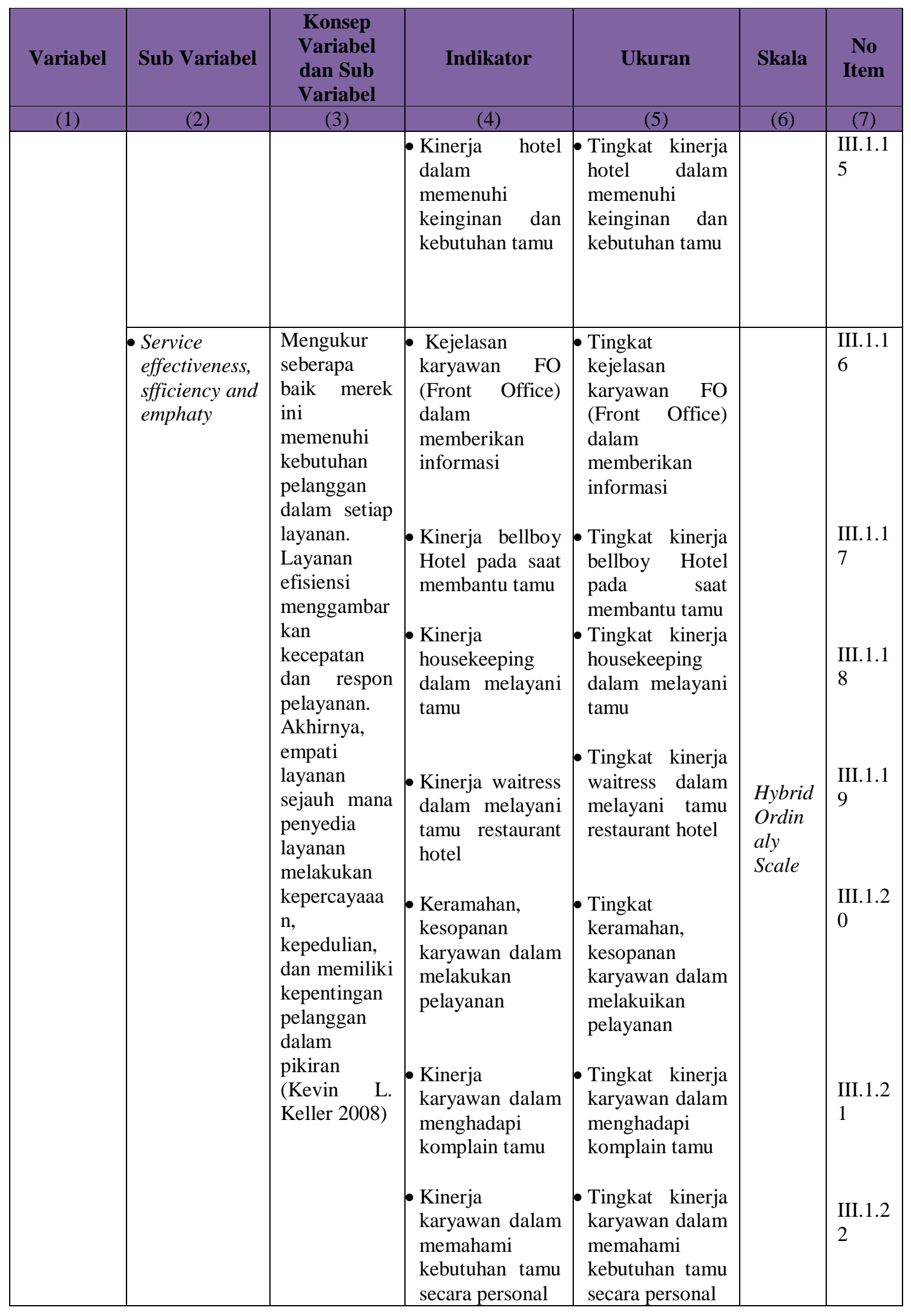

Tourism and Hospitality Essentials (THE) Journal, Vol.II, No.2, 2012 - 372 


\begin{tabular}{|c|c|c|c|c|c|c|}
\hline Variabel & Sub Variabel & $\begin{array}{l}\text { Konsep } \\
\text { Variabel } \\
\text { dan Sub } \\
\text { Variabel }\end{array}$ & Indikator & Ukuran & Skala & $\begin{array}{l}\text { No } \\
\text { Item }\end{array}$ \\
\hline (1) & (2) & (3) & (4) & (5) & (6) & (7) \\
\hline & $\begin{array}{ll}\text { - Style } & \text { and } \\
\text { Design } & \end{array}$ & $\begin{array}{l}\text { Asosiasi } \\
\text { dengan } \\
\text { produk yang } \\
\text { melampaui } \\
\text { aspek } \\
\text { fungsional } \\
\text { untuk } \\
\text { pertimbanga } \\
\text { n estetika } \\
\text { lebih seperti } \\
\text { ukuran, } \\
\text { bentuk, } \\
\text { bahan, } \\
\text { dan warna } \\
\text { yang terlibat, } \\
\text { juga aspek } \\
\text { sensori } \\
\text { seperti } \\
\text { bagaimana } \\
\text { produk } \\
\text { terlihat dan } \\
\text { terasa, dan } \\
\text { mungkin } \\
\text { bahkan apa } \\
\text { yang } \\
\text { terdengar } \\
\text { atau baunya } \\
\text { seperti apa. } \\
\text { (Kevin } \\
\text { L.Keller } \\
\text { 2008) }\end{array}$ & $\begin{array}{l}\text { - Kemenarikan } \\
\text { logo hotel } \\
\text { jayakarta } \\
\text { sebagai } \\
\text { "boutique suite } \\
\text { and spa" } \\
\text { - Kemenarikan } \\
\text { eksterior } \\
\text { bangunan hotel } \\
\text { jayakarta } \\
\text { sebagai } \\
\text { "boutique suite } \\
\text { and spa" } \\
\\
\text { - Kemenarikan } \\
\text { design interior } \\
\text { hotel sebagai } \\
\text { "boutique suite } \\
\text { and spa" } \\
\\
\text { - Kemenarikan } \\
\text { - Kestetika layout } \\
\text { loby hotel } \\
\text { seragam } \\
\text { karyawan hotel } \\
\text { dalam bertugas } \\
\text { - Kemenarikan } \\
\text { design kamar } \\
\text { sebagai } \\
\text { "boutique suite } \\
\text { and spa" } \\
\text { resign interior } \\
\text { sebagarant } \\
\text { "boutique suite } \\
\text { and spa" } \\
\end{array}$ & $\begin{array}{l}\text { - Tingkat } \\
\text { kemenarikan } \\
\text { logo hotel } \\
\text { jayakarta } \\
\text { "boutique suite } \\
\text { and spa" } \\
\text { - Ting } \\
\text { kemenarikan } \\
\text { eksterior } \\
\text { bangunan hotel } \\
\text { jayakarta } \\
\text { sebagai } \\
\text { "boutique suite } \\
\text { and spa" } \\
\text { - Tingkat } \\
\text { kemenarikan } \\
\text { interior hotel } \\
\text { sebagai } \\
\text { "boutique suite } \\
\text { and spa" } \\
\text { - Tingkat } \\
\text { kemenarikan } \\
\text { estetika layout } \\
\text { loby hotel } \\
\text { - Tingkat } \\
\text { kemenarikan } \\
\text { design kamar } \\
\text { sebagai } \\
\text { "boutique suite } \\
\text { and spa" } \\
\text { - Tingkat } \\
\text { kemenarikan } \\
\text { design interior } \\
\text { restaurant } \\
\text { sebagai } \\
\text { "biutique suite } \\
\text { and spa" } \\
\text { - Tingkat } \\
\text { kemenarikan } \\
\text { seragam } \\
\text { karyawan hotel }\end{array}$ & $\begin{array}{l}\text { Hybrid } \\
\text { Ordin } \\
\text { aly } \\
\text { Scale }\end{array}$ & $\begin{array}{l}\text { III.1. } \\
23\end{array}$ \\
\hline
\end{tabular}




\begin{tabular}{|c|c|c|c|c|c|c|}
\hline Variabel & Sub Variabel & $\begin{array}{l}\text { Konsep } \\
\text { Variabel } \\
\text { dan Sub } \\
\text { Variabel }\end{array}$ & Indikator & Ukuran & Skala & $\begin{array}{c}\text { No } \\
\text { Item }\end{array}$ \\
\hline (1) & (2) & (3) & (4) & (5) & (6) & (7) \\
\hline & & & & dalam bertugas & & \\
\hline & - Price & $\begin{array}{l}\text { Asosiasi } \\
\text { kinerja } \\
\text { dimana } \\
\text { konsumen } \\
\text { dapat } \\
\text { mengorganis } \\
\text { ir } \\
\text { pengetahuan } \\
\text { kategori } \\
\text { produk } \\
\text { mereka } \\
\text { dalam hal } \\
\text { tingkatan } \\
\text { harga merek } \\
\text { yang } \\
\text { berbeda } \\
\text { (Kevin L. } \\
\text { Keller) }\end{array}$ & 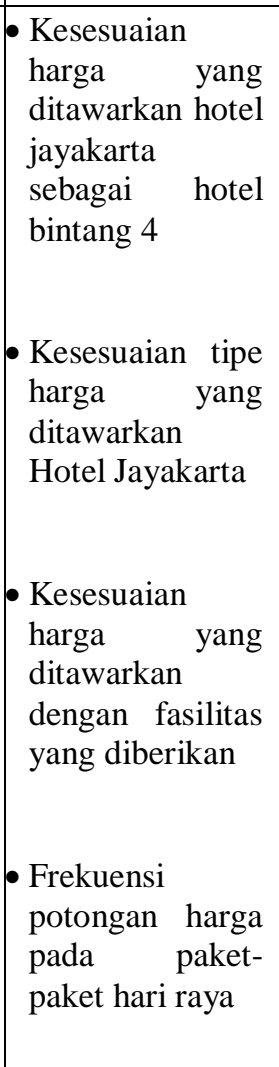 & $\begin{array}{l}\text { - Tingkat } \\
\text { kesesuaian } \\
\text { harga yang } \\
\text { ditawarkan } \\
\text { hotel jayakarta } \\
\text { sebagai hotel } \\
\text { bintang } 4 \\
\text { - Tingkat } \\
\text { kesesuaian tipe } \\
\text { harga yang } \\
\text { ditawarkan } \\
\text { Hotel Jayakarta } \\
\text { - Tingkat } \\
\text { kesesuaian } \\
\text { harga yang } \\
\text { ditawarkan } \\
\text { dengan fasilitas } \\
\text { yang diberikan } \\
\text { - Tingkat } \\
\text { frekuensi } \\
\text { potongan harga } \\
\text { pada paket- } \\
\text { paket hari raya }\end{array}$ & $\begin{array}{l}\text { Hybrid } \\
\text { Ordina } \\
\text { ly } \\
\text { Scale }\end{array}$ & $\begin{array}{l}\text { III.1. } \\
31\end{array}$ \\
\hline $\begin{array}{l}\text { Keputusa } \\
\text { n } \\
\text { Menginap } \\
(Y)\end{array}$ & & \multicolumn{5}{|c|}{$\begin{array}{l}\text { Keputusan pembelian adalah tahap dalam proses pengambilan } \\
\text { keputusan } \\
\text { menginap di mana tamu benar-benar memilih tempat guna menginap. } \\
\text { Kotler dan Keller (2009:226) }\end{array}$} \\
\hline & $\begin{array}{l}\text { - Pemilihan } \\
\text { produk }\end{array}$ & & $\begin{array}{l}\text { - Keputusan } \\
\text { menginap } \\
\text { berdasarkan } \\
\text { produk dan jasa } \\
\text { yang ditawarkan } \\
\text { - Keputusan } \\
\text { menginap } \\
\text { berdasarkan } \\
\text { variasi produk } \\
\text { dan jasa yang } \\
\text { ditawarkan }\end{array}$ & $\begin{array}{l}\text { - Tingkat } \\
\text { keputusan } \\
\text { menginap } \\
\text { berdasarkan } \\
\text { produk dan jasa } \\
\text { yang ditawarkan } \\
\text { - Tingkat } \\
\text { keputusan } \\
\text { menginap } \\
\text { berdasarkan } \\
\text { variasi produk } \\
\text { dan jasa yang }\end{array}$ & $\begin{array}{l}\text { Hybrid } \\
\text { Ordina } \\
\text { ly } \\
\text { Scale }\end{array}$ & $\begin{array}{l}\text { III.1. } \\
1\end{array}$ \\
\hline
\end{tabular}




\begin{tabular}{|c|c|c|c|c|c|c|}
\hline Variabel & Sub Variabel & $\begin{array}{l}\text { Konsep } \\
\text { Variabel } \\
\text { dan Sub } \\
\text { Variabel }\end{array}$ & Indikator & Ukuran & Skala & $\begin{array}{c}\text { No } \\
\text { Item }\end{array}$ \\
\hline (1) & (2) & (3) & (4) & (5) & (6) & (7) \\
\hline & & & & ditawarkan & & \\
\hline & $\begin{array}{l}\text { Pemi } \\
\text { lihan } \\
\text { mere } \\
\mathrm{k}\end{array}$ & & $\begin{array}{l}\text { - Kesadaran } \\
\text { mengenai } \\
\text { adanya hotel } \\
\text { jayakarta } \\
\text { - Frekuensi rekan } \\
\text { kerja atau orang } \\
\text { lain } \\
\text { menyarankan } \\
\text { menginap di } \\
\text { hotel jayakarta } \\
\text { - Citra merek } \\
\text { hotel jayakarta } \\
\text { sebagai } \\
\text { "boutique suite } \\
\text { and spa" }\end{array}$ & $\begin{array}{l}\text { - Tingkat } \\
\text { kesadaran } \\
\text { mengenai } \\
\text { adanya Hotel } \\
\text { Jayakarta } \\
\text { - Tingkat } \\
\text { frekuensi rekan } \\
\text { kerja atau orang } \\
\text { lain } \\
\text { menyarankan } \\
\text { menginap di } \\
\text { Hotel Jayakarta } \\
\text { - Tingkat citra } \\
\text { merek hotel } \\
\text { jayakarta } \\
\text { sebagai } \\
\text { "boutique suite } \\
\text { and spa" }\end{array}$ & $\begin{array}{l}\text { Hybrid } \\
\text { Ordin } \\
\text { aly } \\
\text { Scale }\end{array}$ & $\begin{array}{l}\begin{array}{l}\text { III.1. } \\
3\end{array} \\
\text { III.1. } \\
4\end{array}$ \\
\hline & $\begin{array}{l}\text { - Pemilihan } \\
\text { saluran } \\
\text { reservasi }\end{array}$ & & $\begin{array}{l}\text { - Keputusan } \\
\text { menginap } \\
\text { melalui walk-in } \\
\text { (langsung) } \\
\text { - Keputusan } \\
\text { menginap } \\
\text { melalui travel } \\
\text { agent } \\
\text { - Keputusan } \\
\text { menginap via } \\
\text { telepon }\end{array}$ & $\begin{array}{l}\text { - Tingkat } \\
\text { keputusan } \\
\text { menginap } \\
\text { melalui walk-in } \\
\text { (langsung) } \\
\text { - Tingkat } \\
\text { keputusan } \\
\text { menginap } \\
\text { melalui travel } \\
\text { agent } \\
\text { - Tingkat } \\
\text { keputusan } \\
\text { menginap via } \\
\text { telepon }\end{array}$ & $\begin{array}{l}\text { Hybrid } \\
\text { Ordin } \\
\text { aly } \\
\text { Scale }\end{array}$ & $\begin{array}{l}\text { III.1. } \\
7\end{array}$ \\
\hline & $\begin{array}{l}\text { - Waktu } \\
\text { menginap }\end{array}$ & & $\begin{array}{l}\text { - Menginap pada } \\
\text { saat weekend } \\
\text { - Menginap pada } \\
\text { saat hari libur }\end{array}$ & $\begin{array}{l}\text { - Tingkat } \\
\text { menginap pada } \\
\text { saat weekend } \\
\text { - Tingkat } \\
\text { menginap pada } \\
\text { saat hari libur }\end{array}$ & $\begin{array}{l}\text { Hybrid } \\
\text { Ordin } \\
\text { aly } \\
\text { Scale }\end{array}$ & $\begin{array}{l}\text { III.1. } \\
9 \\
\text { III. } 1 . \\
10\end{array}$ \\
\hline & $\begin{array}{l}\text { - Jumlah } \\
\text { pemesanan } \\
\text { kamar }\end{array}$ & & $\begin{array}{l}\text { - Keputusan } \\
\text { menginap } \\
\text { berdasarkan } \\
\text { paket-paket } \\
\text { yang ditawarkan }\end{array}$ & $\begin{array}{l}\text { - Tingkat } \\
\text { keputusan } \\
\text { menginap } \\
\text { berdasarkan } \\
\text { paket-paket } \\
\text { yang ditawarkan }\end{array}$ & $\begin{array}{l}\text { Hybrid } \\
\text { Ordin } \\
\text { aly } \\
\text { Scale }\end{array}$ & $\begin{array}{l}\text { III.1. } \\
11\end{array}$ \\
\hline
\end{tabular}




\begin{tabular}{|c|c|c|c|c|c|c|}
\hline Variabel & Sub Variabel & $\begin{array}{l}\text { Konsep } \\
\text { Variabel } \\
\text { dan Sub } \\
\text { Variabel }\end{array}$ & Indikator & Ukuran & Skala & $\begin{array}{l}\text { No } \\
\text { Item }\end{array}$ \\
\hline \multirow[t]{3}{*}{ (1) } & (2) & (3) & (4) & (5) & (6) & (7) \\
\hline & & & $\begin{array}{l}\text { - Keputusan } \\
\text { menginap } \\
\text { berdasarkan } \\
\text { potongan harga } \\
\text { yang ditawarkan }\end{array}$ & $\begin{array}{l}\text { - Tingkat } \\
\text { keputusan } \\
\text { menginap } \\
\text { berdasarkan } \\
\text { potongan harga } \\
\text { yang ditawarkan }\end{array}$ & & $\begin{array}{l}\text { III.1. } \\
12\end{array}$ \\
\hline & $\begin{array}{l}\text { - Metode } \\
\text { Pembayaran }\end{array}$ & & $\begin{array}{l}\text { - Keputusan } \\
\text { menginap } \\
\text { dengan } \\
\text { melakukan } \\
\text { pembayaran } \\
\text { melalui kartu } \\
\text { kredit } \\
\text { - Keputusan } \\
\text { menginap } \\
\text { dengan } \\
\text { melakukan } \\
\text { pembayaran } \\
\text { melalui uang } \\
\text { tunai }\end{array}$ & $\begin{array}{l}\text { - Tingkat } \\
\text { keputusan } \\
\text { menginap } \\
\text { dengan } \\
\text { melakukan } \\
\text { pembayaran } \\
\text { melalui kartu } \\
\text { kredit } \\
\text { - Tingkat } \\
\text { keputusan } \\
\text { menginap } \\
\text { dengan } \\
\text { melakukan } \\
\text { pembayaran } \\
\text { melalui uang } \\
\text { tunai }\end{array}$ & $\begin{array}{l}\text { Hybrid } \\
\text { Ordin } \\
\text { aly } \\
\text { Scale }\end{array}$ & $\begin{array}{l}\text { III.1. } \\
13\end{array}$ \\
\hline
\end{tabular}

Sumber: Hasil pengolahan data, 2011

\subsection{Metode Penarikan Sampel}

Sampel minimal dalam penelitian ini setelah dijumlahkan antara proporsi sampel di The Jayakarta Bandung Boutique Suite Hotel $\&$ Spa yaitu sebesar 100 responden.

\subsection{Prosedur Pengumpulan Data}

Pengumpulan data yang dilakukan penulis menggunakan teknik sebagai berikut.:

1. Wawancara

2. Observasi

3. Studi literatur

4. Angket/kuesioner

\subsection{Pengujian Hipotesis}

Sebagai langkah terakhir dari analisis data adalah pengujian hipotesis. Teknik analisis data yang digunakan dalam penelitian ini adalah metode analisis verifikatif, maka dilakukan analisis jalur (path analysis). Dalam hal ini, analisis jalur digunakan untuk menentukan besarnya pengaruh variabel independen $(\mathrm{X})$ terhadap variabel dependen
(Y) baik secara langsung ataupun tidak langsung.

Analisis jalur digunakan untuk menentukan besarnya pengaruh variabel independen $(\mathrm{X})$ yaitu Brand Performance yang terdiri dari Primary ingredients and supplementary features (X1.1), Product reliability, durability, and serviceability (X1.2), Service effectiveness, efficiency, and empathy (X1.3), Style dan design (X1.4), Price (X1.5) terhadap variabel dependen (Y) yaitu Keputusan Menginap.

Data yang diperoleh dalam penelitian ini adalah data gabungan skala interval-ordinal (hybrid ordinal-interval scale) yaitu merupakan suatu skala yang secara artifisial ditransformasikan ke dalam apa yang diasumsikan sebagai skala interval. Hybrid Ordinal-interval scale pada dasarnya adalah skala ordinal tetapi diasumsikan memiliki karakteristik jarak yang diasumsikan (assumed distance property) sehingga peneliti dapat melakukan beberapa analisis statistik yang 
tingkatannya lebih tinggi (advance statistic analysis) (Hermawan, 2006: 123)

\section{Analisis Jalur (Path Analysis)}

Selanjutnya akan ditentukan pasangan data variabel independen dari semua sampel penelitian. Berdasarkan hipotesis konseptual yang diajukan, terdapat hubungan antara variabel penelitian. Hipotesis tersebut digambarkan dalam sebuah paradigma seperti terlihat pada Gambar 3.1 berikut:

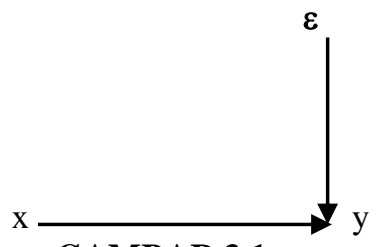

GAMBAR 3.1

STRUKTUR KAUSAL ANTARA X DAN Y

Keterangan:

$\mathbf{X}=$ Analisis Brand Performance

$\mathbf{Y}=$ Keputusan Menginap

$\boldsymbol{\varepsilon}=$ Epsilon (variabel lain)

Struktur hubungan di atas menunjukkan bahwa Brand Performance berpengaruh terhadap Keputusan Menginap. Selain itu terdapat faktor-faktor lain yang mempengaruhi hubungan antara Brand Performance dan Keputusan Menginap yaitu variabel residu dan dilambangkan dengan $\varepsilon$, namun pada penelitian ini variabel tersebut tidak diperhatikan.

Struktur hubungan antara Brand Performance $\left(\mathrm{X}_{1}\right)$ dan Keputusan Menginap (Y) diuji melalui analisis jalur dengan hipotesis yang berbunyi terdapat pengaruh yang signifikan antara Brand Performance $\left(\mathrm{X}_{1}\right)$ yang terdiri dari, Primary ingredients and supplementary features $\left(\mathrm{X}_{1.1}\right)$, Product reliability, durability, and serviceability $\left(\mathrm{X}_{1.2}\right)$, Service effectiveness, efficiency, and empathy $\left(\mathrm{X}_{1.3}\right)$, Style and design $\left(\mathrm{X}_{1.4}\right)$, and Price $\left(\mathrm{X}_{1.5}\right)$, terhadap Keputusan Menginap (Y).

a. Menguji pengaruh langsung maupun tidak langsung dari setiap variabel.

\section{Pengaruh X Terhadap Y \\ Pengaruh $\left(\mathrm{X}_{1}\right)$ terhadap $(\mathrm{Y})$ \\ Pengaruh langsung $=\mathrm{PYX}_{1} \cdot \mathrm{PYX}_{1}$ \\ Pengaruh tidak langsung melalui $\left(\mathrm{X}_{2}\right)$ $=\mathrm{PYX}_{1} \cdot \mathrm{rX}_{1} \mathrm{X}_{2} \cdot \mathrm{PYX}_{2}$}

Pengaruh tidak langsung melalui $\left(\mathrm{X}_{3}\right)$ $=\mathrm{PYX}_{1} \cdot \mathrm{rX}_{1} \mathrm{X}_{3} \cdot \mathrm{PYX}_{3}$

Pengaruh tidak langsung melalui $\left(\mathrm{X}_{4}\right)$ $=\mathrm{PYX}_{1} \cdot \mathrm{rX}_{1} \mathrm{X}_{4} \cdot \mathrm{PYX}_{4}$

Pengaruh tidak langsung melalui $\left(\mathrm{X}_{5}\right)$ $=\underline{\mathrm{PYX}}_{1} \cdot \underline{\mathrm{rX}}_{1} \underline{\mathrm{X}}_{5} \cdot \mathrm{PYX}_{5}+$

Pengaruh total $\left(X_{1}\right)$ terhadap $Y=\ldots .$.

Pengaruh $\left(\mathbf{X}_{2}\right)$ terhadap (Y)

Pengaruh langsung $=\mathrm{PYX}_{2} \cdot \mathrm{PYX}_{2}$

Pengaruh tidak langsung melalui $\left(\mathrm{X}_{1}\right)$ $=\mathrm{PYX}_{2} \cdot \mathrm{rX}_{2} \mathrm{X}_{1} \cdot \mathrm{PYX}_{1}$

Pengaruh tidak langsung melalui $\left(\mathrm{X}_{3}\right)$ $=\mathrm{PYX}_{2} \cdot \mathrm{rX}_{2} \mathrm{X}_{3} \cdot \mathrm{PYX}_{3}$

Pengaruh tidak langsung melalui $\left(\mathrm{X}_{4}\right)$ $=\mathrm{PYX}_{2} \cdot \mathrm{rX}_{2} \mathrm{X}_{4} \cdot \mathrm{PYX}_{4}$

Pengaruh tidak langsung melalui $\left(\mathrm{X}_{5}\right)$ $=\underline{\mathrm{PYX}}_{2} \cdot \underline{\mathrm{rX}}_{2} \underline{\mathrm{X}}_{5} \cdot \mathrm{PYX}_{5}+$

Pengaruh total $\left(X_{2}\right)$ terhadap $Y=\ldots . .$.

Pengaruh $\left(\mathbf{X}_{3}\right)$ terhadap $(\mathbf{Y})$

Pengaruh langsung $=\mathrm{PYX}_{3} \cdot \mathrm{PYX}_{3}$

Pengaruh tidak langsung melalui $\left(\mathrm{X}_{1}\right)$ $=\mathrm{PYX}_{3} \cdot \mathrm{rX}_{3} \mathrm{X}_{1} \cdot \mathrm{PYX}_{1}$

Pengaruh tidak langsung melalui $\left(\mathrm{X}_{2}\right)$ $=\mathrm{PYX}_{3} \cdot \mathrm{rX}_{3} \mathrm{X}_{2} \cdot \mathrm{PYX}_{2}$

Pengaruh tidak langsung melalui $\left(\mathrm{X}_{4}\right)$ $=\mathrm{PYX}_{3} \cdot \mathrm{rX}_{3} \mathrm{X}_{4} \cdot \mathrm{PYX}_{4}$

Pengaruh tidak langsung melalui $\left(\mathrm{X}_{5}\right)$ $=\underline{P Y X}_{3} \cdot \mathrm{rX}_{3} \underline{X}_{5} \cdot \mathrm{PYX}_{5}+$

Pengaruh total $\left(\mathrm{X}_{3}\right)$ terhadap $\mathrm{Y}=\ldots . .$.

Pengaruh $\left(\mathrm{X}_{4}\right)$ terhadap $(\mathrm{Y})$

Pengaruh langsung $=\mathrm{PYX}_{4} \cdot \mathrm{PYX}_{4}$

Pengaruh tidak langsung melalui $\left(\mathrm{X}_{1}\right)$ $=\mathrm{PYX}_{4} \cdot \mathrm{rX}_{4} \mathrm{X}_{1} \cdot \mathrm{PYX}_{1}$

Pengaruh tidak langsung melalui $\left(\mathrm{X}_{2}\right)$ $=\mathrm{PYX}_{4} \cdot \mathrm{rX}_{4} \mathrm{X}_{2} \cdot \mathrm{PYX}_{2}$

Pengaruh tidak langsung melalui $\left(\mathrm{X}_{3}\right)$ $=\mathrm{PYX}_{4} \cdot \mathrm{rX}_{4} \mathrm{X}_{3} \cdot \mathrm{PYX}_{3}$

Pengaruh tidak langsung melalui $\left(\mathrm{X}_{5}\right)$ $=\underline{\mathrm{PYX}}_{4} \cdot \mathrm{rX}_{4} \underline{\mathrm{X}}_{5} \cdot \mathrm{PYX}_{5}+$

Pengaruh total $\left(\mathrm{X}_{4}\right)$ terhadap $\mathrm{Y}=\ldots . .$.

Pengaruh $\left(\mathrm{X}_{5}\right)$ terhadap $(\mathrm{Y})$

Pengaruh langsung $=\mathrm{PYX}_{5} \cdot \mathrm{PYX}_{5}$

Pengaruh tidak langsung melalui $\left(\mathrm{X}_{1}\right)$ $=\mathrm{PYX}_{5} \cdot \mathrm{rX}_{5} \mathrm{X}_{1} \cdot \mathrm{PYX}_{1}$

Pengaruh tidak langsung melalui $\left(\mathrm{X}_{2}\right)$ $=\mathrm{PYX}_{5} \cdot \mathrm{rX}_{5} \mathrm{X}_{2} \cdot \mathrm{PYX}_{2}$ 
Pengaruh tidak langsung melalui $\left(\mathrm{X}_{3}\right)$ $=\mathrm{PYX}_{5} \cdot \mathrm{rX}_{5} \mathrm{X}_{3} \cdot \mathrm{PYX}_{3}$

Pengaruh tidak langsung melalui $\left(\mathrm{X}_{4}\right)$ $=\underline{\mathrm{PYX}}_{5} \cdot \mathrm{rX}_{5} \underline{\mathrm{X}}_{4} \cdot \mathrm{PYX}_{4}+$

Pengaruh total $\left(\mathrm{X}_{5}\right)$ terhadap $\mathrm{Y}=\ldots . .$.

b. Menghitung pengaruh variabel lain $(\mathcal{E})$ dengan rumus sebagai berikut:

$$
P_{Y \varepsilon}=\sqrt{1-R_{Y(X 1, X 2, \ldots, X 5)}^{2}}
$$

Secara statistik hipotesis yang akan di uji berada pada taraf kesalahan 0,05 dengan derajat kebebasan dk (n-2). Kriteria penerimaan atau penolakan hipotesis pada penelitian ini dapat ditulis sebagai berikut:

1. $\mathrm{H}_{0}: \rho=0$, artinya tidak terdapat pengaruh yang signifikan antara brand performance yang terdiri dari Primary ingredients and supplementary features, Product reliability, durability, and serviceability, Service effectiveness, efficiency, and empathy, Style and design, dan Price.

2. $\mathrm{H}_{0}: \rho>0$, artinya terdapat pengaruh yang signifikan antara brand performance yang terdiri dari Primary ingredients and supplementary features, Product reliability, durability, and serviceability, Service effectiveness, efficiency, and empathy, Style and design, dan Price.

\section{HASIL PENELITIAN DAN} PEMBAHASAN

4.1 Tanggapan Tamu terhadap brand performance

Relapitulasi Hasil Tanggapan Tamu The Jayakarta Bandung Boutique Suite Hotel \& Spa Terhadap Brand Performance.

TABEL 4.1

\section{REKAPITULASI TANGGAPAN TAMU} THE JAYAKARTA BANDUNG BOUTIQUE SUITE HOTEL \& SPA TERHADAP BRAND PERFORMANCE

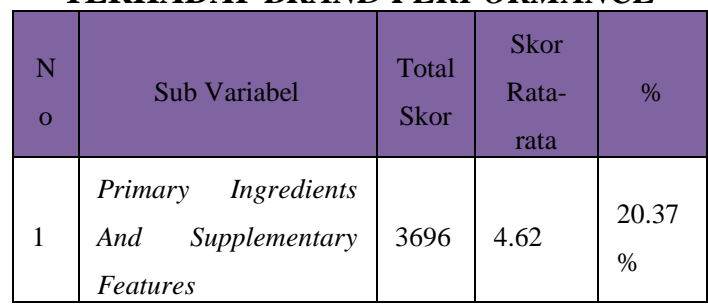

\begin{tabular}{|l|l|l|l|l|}
\hline 2 & $\begin{array}{l}\text { Product Reliability, } \\
\text { Durability and Service } \\
\text { Ability }\end{array}$ & 3338 & 4.76 & $\begin{array}{l}20.99 \\
\%\end{array}$ \\
\hline 3 & $\begin{array}{l}\text { Service Effectiveness, } \\
\text { Efficiency, And } \\
\text { Empathy }\end{array}$ & 2968 & 4.24 & $\begin{array}{l}18.69 \\
\%\end{array}$ \\
\hline 4 & Style and Design & 3245 & 4.63 & $\begin{array}{l}20.41 \\
\%\end{array}$ \\
\hline 5 & Price & 1772 & 4.43 & $\begin{array}{l}19.54 \\
\%\end{array}$ \\
\hline & Total & 1505 & 22.68 & $100 \%$ \\
\hline
\end{tabular}

Sumber: Pengolahan data, 2011

Berdasarkan Tabel 4.1 dapat terlihat bahwa sub variabel dari brand performance di The Jayakarta Bandung Boutique Suite Hotel \& Spa yang mendapatkan penilaian tertinggi yaitu pada Product Reliability, Durability and Service Ability sebesar $20.99 \%$. Hal ini disebabkan oleh produk yang terdapat di The Jayakarta Bandung Boutique Suite Hotel \& Spa cukup menarik tamu untuk menginap dan adanya kemudahan untuk melakukan aktivitas di hotel, Sedangkan sub variabel yang mendapatkan penilaian terendah yaitu Service Effectiveness, Efficiency, And Empathy sebesar $18.69 \%$. Hal ini disebabkan karena masih terdapat complain tamu yang kurang cepat ditanggapi oleh pihak hotel, sehingga membuat tamu tidak merasa terkesan, dan komunikasi dalam menyampaikan pelayanan terhadap tamu yang dianggap belum memprioritaskan tamu.

Komunikasi merupakan hal yang penting sebagaimana yang dikemukakan oleh Fiona Harris (2003:447) dalam jurnal corporate branding and corporate brand performance mengemukakan bahwa "the factors of brand performance is similarity of brand team members, shared values and communication".

\subsection{Tanggapan Tamu terhadap keputusan menginap}

Rekapitulasi Hasil Tanggapan Tamu terhadap Keputusan Menginap di The Jayakarta Bandung Boutique Suite Hotel \& Spa pada gambar 4.2. 


\begin{tabular}{|c|c|c|c|c|}
\hline \multicolumn{5}{|c|}{$\begin{array}{c}\text { TABEL } 4.2 \\
\text { REKAPITULASI HASIL TANGGAPAN } \\
\text { TAMU TERHADAP KEPUTUSAN } \\
\text { MENGINAP THE JAYAKARTA } \\
\text { BANDUNG BOUTIQUE SUITE HOTEL \& } \\
\text { SPA }\end{array}$} \\
\hline No & $\begin{array}{c}\text { Sub } \\
\text { Variabel }\end{array}$ & $\begin{array}{l}\text { Total } \\
\text { Skor }\end{array}$ & $\begin{array}{c}\text { Skor } \\
\text { Rata- } \\
\text { rata }\end{array}$ & $\%$ \\
\hline 1 & $\begin{array}{l}\text { Keputusan } \\
\text { Menginap } \\
\text { Berdasarkan } \\
\text { Pemilihan } \\
\text { Produk }\end{array}$ & 938 & 4.69 & $16.83 \%$ \\
\hline 2 & $\begin{array}{l}\text { Keputusan } \\
\text { Menginap } \\
\text { Berdasarkan } \\
\text { pemilihan } \\
\text { merek }\end{array}$ & 1482 & 4.94 & $17.73 \%$ \\
\hline 3 & $\begin{array}{l}\text { Keputusan } \\
\text { Menginap } \\
\text { Berdasarkan } \\
\text { Saluran } \\
\text { Distribusi }\end{array}$ & 1375 & 4.58 & $16.44 \%$ \\
\hline 4 & $\begin{array}{l}\text { Keputusan } \\
\text { Menginap } \\
\text { Berdasarkan } \\
\text { Waktu } \\
\end{array}$ & 912 & 4.56 & $16.37 \%$ \\
\hline 5 & $\begin{array}{l}\text { Keputusan } \\
\text { Menginap } \\
\text { Berdasarkan } \\
\text { Jumlah } \\
\text { Pembelian } \\
\end{array}$ & 910 & 4.55 & $16.34 \%$ \\
\hline 6 & $\begin{array}{l}\text { Keputusan } \\
\text { Menginap } \\
\text { Berdasarkan } \\
\text { Metode } \\
\text { Pembayaran }\end{array}$ & 909 & 4.54 & $16.29 \%$ \\
\hline & Total & 3042 & 27.86 & $100 \%$ \\
\hline
\end{tabular}

Sumber: Pengolahan data, 2011

Berdasarkan Tabel 4.2 dapat terlihat bahwa sub variabel dari keputusan menginap The Jayakarta Bandung Boutique Suite Hotel \& Spa yang mendapatkan penilaian tertinggi yaitu pada keputusan menginap berdasarkan pemilihan merek yaitu sebesar $17.73 \%$. Hal tersebut terjadi karena rata-rata tamu hotel menginap telah mengenal merek The Jayakarta Bandung Boutique Suite Hotel \& Spa terlebih dahulu, hal tersebut di perkuat oleh pernyataan dari Kotler dan Armstrong (2008:137), konsumen harus mengambil keputusan tentang merek mana yang akan dibeli. Setiap merek memiliki perbedaan-perbedaan tersendiri. Dalam hal ini perusahaan harus mengetahui bagaimana konsumen memiiki sebuah merek.

Sedangkan penilaian terendah terjadi pada pernyataan keputusan menginap berdasarkan metode pembayaran yaitu sebesar $16.29 \%$. hal tersebut terjadi karena selalu adanya gangguan dalam melakukan pembayaran, yang membuat tamu tidak merasa nyaman, sehingga pengaruh untuk metode pembayaran sangat dirasa kurang baik oleh tamu yang menginap di The Jayakarta Bandung Boutique Suite Hotel \& Spa.

\subsection{Pengaruh Brand Performance Terhadap keputusan tamu untuk menginap di hotel jayakarta bandung \\ Pengujian hipotesis dilakukan untuk} menguji besarnya pengaruh brand Performance (X) yang terdiri dari yaitu primary ingredients and supplementary features $\left(\mathrm{X}_{1.1}\right)$, product reliability, durability, and serviceability $\left(\mathrm{X}_{1.2}\right)$,, service effectiveness, efficiency, and empathy $\left(\mathrm{X}_{1.3}\right)$,, style and design $\left(\mathrm{X}_{1.4}\right)$,, dan price $\left(\mathrm{X}_{1.5}\right)$,. terhadap keputusan menginap $(\mathrm{Y})$

Berdasarkan hasil matriks korelasi antara sub variabel brand performance terhadap keputuan menginap diperoleh hasil korelasi secara berurutan yaitu, primary ingredients and supplementary features (0.489), product reliability, durability, and serviceability (0.081),, service effectiveness, efficiency, and empathy (0.088), style and design (0.369),, dan price (0.478).

Sub variabel product reliability, durability, and serviceability memiliki nilai korelasi terbesar hal disebabkan oleh adanya kesesuaian antara pelayanan dan keandalan yang diterapkan oleh management The Jayakarta Bandung Boutique Suite Hotel \& Spa kepada para tamu, sehingga membuat tamu merasa nyaman dengan suasana di The Jayakarta Bandung Boutique Suite Hotel \& Spa. Sedangkan service effectiveness, efficiency, and empathy mempunyai nilai korelasi terendah hal tersebut dikarenakan The Jayakarta Bandung Boutique Suite Hotel \& Spa belum dapat memberikan pelayanan yang diharapkan oleh tamu yang menginap di The Jayakarta Bandung Boutique Suite Hotel \& Spa. 


\section{Uji Keseluruhan (Uji F) / Simultan}

Pengujian signifikasi dapat digunakan uji $\mathrm{F}$, berdasarkan hasil pengujian hipotesis melalui SPSS 18.0 pengujian secara keseluruhan (Uji F), disajikan dalam Tabel 4.3

TABEL 4.3

UJI KESELURUHAN (UJI F)

\begin{tabular}{|c|c|c|c|c|c|c|}
\hline \multicolumn{2}{|c|}{ Model } & $\begin{array}{l}\text { Sum } \\
\text { of } \\
\text { Squa } \\
\text { res }\end{array}$ & $\mathrm{df}$ & $\begin{array}{c}\text { Mea } \\
\mathrm{n} \\
\text { Squa } \\
\text { re }\end{array}$ & $\mathrm{F}$ & Sig. \\
\hline \multirow{3}{*}{1} & $\begin{array}{l}\text { Regres } \\
\text { sion }\end{array}$ & $\begin{array}{l}53, \\
729\end{array}$ & 5 & $\begin{array}{l}10, \\
746\end{array}$ & \multirow[t]{3}{*}{$\begin{array}{l}22, \\
313\end{array}$} & \multirow{3}{*}{$\begin{array}{l}, 0 \\
00 \\
\mathrm{a}\end{array}$} \\
\hline & $\begin{array}{l}\text { Residu } \\
\text { al }\end{array}$ & $\begin{array}{l}45, \\
271\end{array}$ & $\begin{array}{l}9 \\
4\end{array}$ & $\begin{array}{l}, 48 \\
2\end{array}$ & & \\
\hline & Total & $\begin{array}{l}99, \\
000\end{array}$ & $\begin{array}{l}9 \\
9 \\
\end{array}$ & & & \\
\hline
\end{tabular}

Sumber: Pengolahan Data, 2011

Berdasarkan Tabel 4.3 diatas, diperoleh nilai $\mathrm{F}_{\text {hitung }}=22,313$ sedangkan $\mathrm{F}_{\text {tabel }}$ dengan derajat kebebasan pada $\alpha(0.05)$ adalah sebesar 2.31 Dengan demikian $F_{\text {hitung }}(67.164)>F_{\text {tabel }}$ (2.31) dengan nilai signifikansinya 0.000 . Nilai signifikansi lebih kecil dari taraf signifikansi 5\%, sehingga jelas H0 ditolak dan Ha diterima. Dengan nilai signifikansi 0.000 nilai signifikansi lebih kecil dari taraf signifikansi $5 \%$ sehingga dapat diambil kesimpulan bahwa Ho ditolak oleh karena secara keseluruhan model fit dan bisa dilakukan uji secara parsial

\section{Uji Parsial}

Hasil pengujian secara keseluruhan memberikan hasil yang signifikan, maka untuk mengetahui variabel bebas mana yang secara parsial berpengaruh nyata terhadap $\mathrm{Y}$ dapat dilanjutkan dengan pengujian secara parsial. Pengujian koefisien jalur dapat dilihat sebagai berikut:

TABEL 4.4

PENGUJIAN PARSIAL

\begin{tabular}{|c|l|l|l|l|l|l|}
\hline $\begin{array}{c}\mathrm{N} \\
\mathrm{o}\end{array}$ & \multicolumn{2}{|c|}{$\begin{array}{c}\text { Koefisien } \\
\text { Jalur }\end{array}$} & $\begin{array}{c}\mathrm{t} \\
\text { hitu } \\
\mathrm{ng}\end{array}$ & $\begin{array}{c}\mathrm{t} \\
\text { tab } \\
\mathrm{el}\end{array}$ & $\begin{array}{l}\text { Keput } \\
\text { usan }\end{array}$ & $\begin{array}{l}\text { Kesim } \\
\text { pulan }\end{array}$ \\
\hline 1 & $\begin{array}{l}\mathrm{P}_{\mathrm{yx}} \\
1.1\end{array}$ & $\begin{array}{c}4 \\
02\end{array}$ & $\begin{array}{l}5, \\
56 \\
3\end{array}$ & $\begin{array}{l}1.6 \\
75\end{array}$ & $\begin{array}{l}\mathrm{H}_{0} \\
\text { ditola } \\
\mathrm{k}\end{array}$ & $\begin{array}{l}\text { Signifi } \\
\text { kan }\end{array}$ \\
\hline 2 & $\begin{array}{l}\mathrm{P}_{\mathrm{yx}} \\
1.2\end{array}$ & $\begin{array}{l}2 \\
57\end{array}$ & $\begin{array}{l}3, \\
50\end{array}$ & $\begin{array}{l}1.6 \\
75\end{array}$ & $\begin{array}{l}\mathrm{H}_{0} \\
\text { ditola } \\
\mathrm{k}\end{array}$ & $\begin{array}{l}\text { Signifi } \\
\text { kan }\end{array}$ \\
\hline 3 & $\begin{array}{l}\mathrm{P}_{\mathrm{yx}} \\
1.3\end{array}$ & $\begin{array}{l}1 \\
41\end{array}$ & $\begin{array}{l}1, \\
98\end{array}$ & $\begin{array}{l}1.6 \\
75\end{array}$ & $\begin{array}{l}\mathrm{H}_{0} \\
\text { ditola }\end{array}$ & $\begin{array}{l}\text { Signifi } \\
\text { kan }\end{array}$ \\
\hline
\end{tabular}

\begin{tabular}{|c|l|l|l|l|l|l|}
\hline $\begin{array}{c}\mathrm{N} \\
\mathrm{o}\end{array}$ & $\begin{array}{c}\text { Koefisien } \\
\text { Jalur }\end{array}$ & $\begin{array}{c}\mathrm{t} \\
\text { hitu } \\
\mathrm{ng}\end{array}$ & $\begin{array}{c}\mathrm{t} \\
\text { tab } \\
\mathrm{el}\end{array}$ & $\begin{array}{l}\text { Keput } \\
\text { usan }\end{array}$ & $\begin{array}{l}\text { Kesim } \\
\text { pulan }\end{array}$ \\
\hline & & & 1 & & $\mathrm{k}$ & \\
\hline 4 & $\begin{array}{l}\mathrm{P}_{\mathrm{yx}} \\
1.4\end{array}$ & $\begin{array}{l}3 \\
54\end{array}$ & $\begin{array}{l}4, \\
83\end{array}$ & $\begin{array}{l}1.6 \\
2\end{array}$ & $\begin{array}{l}\mathrm{H}_{0} \\
\text { ditola } \\
\mathrm{k}\end{array}$ & $\begin{array}{l}\text { Signifi } \\
\text { kan }\end{array}$ \\
\hline 5 & $\begin{array}{l}\mathrm{P}_{\mathrm{yx}} \\
1.5\end{array}$ & $\begin{array}{r}3 \\
2\end{array}$ & $\begin{array}{l}5, \\
11 \\
5\end{array}$ & $\begin{array}{l}1.6 \\
75\end{array}$ & $\begin{array}{l}\mathrm{H}_{0} \\
\text { ditola } \\
\mathrm{k}\end{array}$ & $\begin{array}{l}\text { Signifi } \\
\text { kan }\end{array}$ \\
\hline
\end{tabular}

Sumber : Pengolahan Data, 2011

Secara lengkap pengaruh masing-masing brand performance terhadap keputusan menginap disajikan dalam Gambar 4.1 


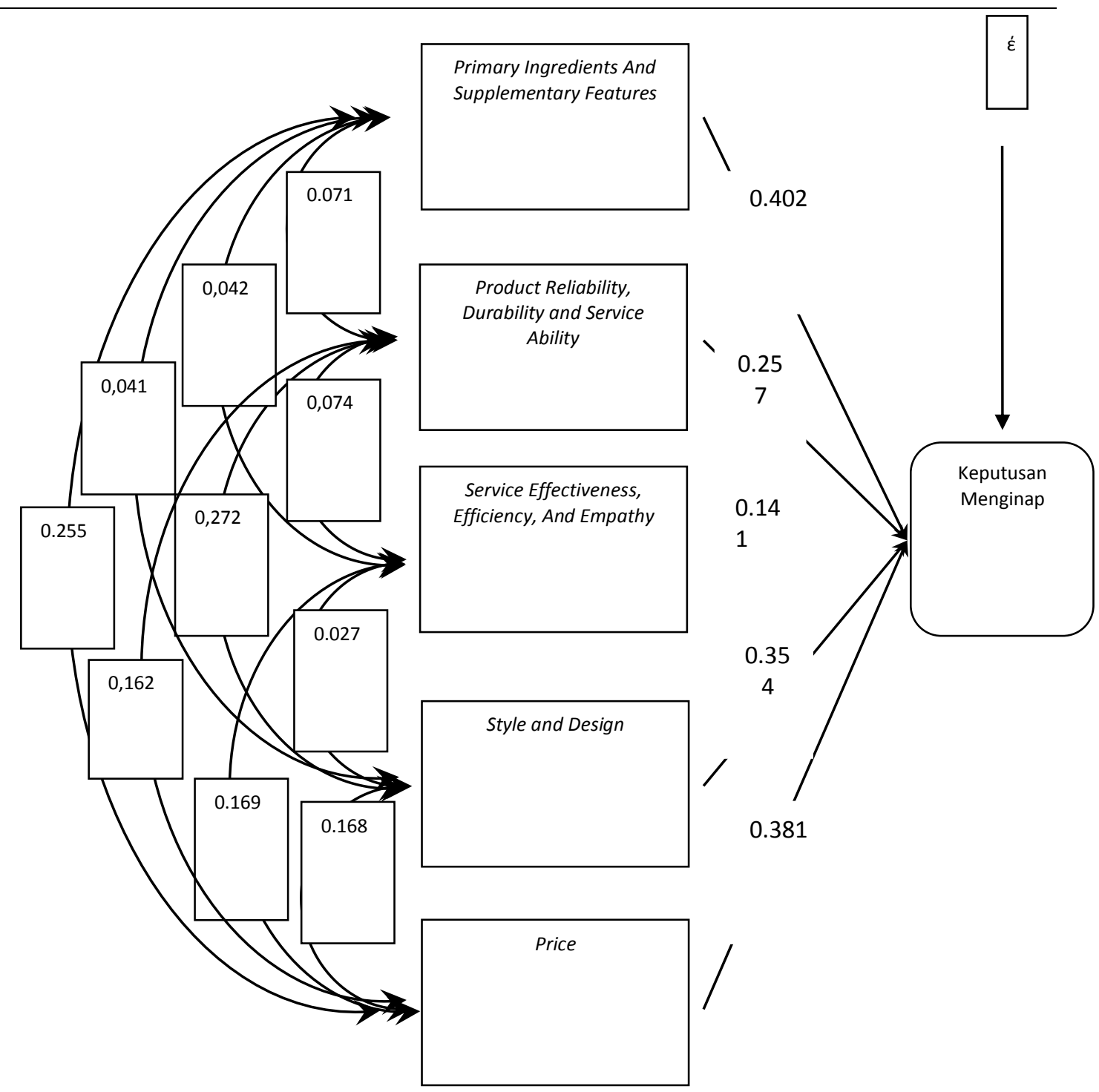

GAMBAR 4.1

PENGARUH BRAND PERFOMANCE TERHADAP KEPUTUSAN BERKUNJUNG

Sumber : Pengolahan Data, 2011

Berdasarkan hasil korelasi selanjutnya akan dilakukan uji $\mathrm{F}$ untuk mengetahui hasil hipotesis. Besarnya nilai korelasi di atas dibuktikan dengan penolakan Ho yang dilakukan dengan uji $\mathrm{F}$ tingkat signifikan (sig) sama dengan 0,000 atau lebih kecil dari 0,05.

Pengujian hipotesis melalui nilai signifikansi dan uji-t menghasilkan penolakan terhadap Ho, karena ada nilai signifikansi lebih kecil dibandingkan dengan 0,05 . Hal 
tersebut berarti bahwa terdapat pengaruh yang signifikan antara primary ingredients and supplementary features, product reliability, durability, and service ability, service effectiveness, efficiency, and empathy, style and design, dan price. terhadap keputusan menginap di The Jayakarta Bandung Boutique Suite Hotel \& Spa.

Penerimaan terhadap hipotesis didukung dengan fakta bahwa brand performance khususnya product reliability, durability, and service ability memang sangat berguna dalam menentukan peningkatan keputusan menginap di Hotel Jayakarta. Hal tersebut sejalan dengan pendapat Kevin L. Keller (2008:64) Brand Performance is "Describes how well the product or service meets customers more functional needs". Artinya bagaimana kemampuan produk dan jasa dalam memenuhi kebutuhan fungsional konsumen.

Berdasarkan hasil perhitungan di atas dapat diketahui bahwa pengaruh program Brand performance terhadap keputusan menginap adalah sebesar 0,643 sedangkan koefisien jalur variabel lain di luar variabel brand performance ditentukan melalui :

$$
\begin{aligned}
P_{Z \varepsilon} & =\sqrt{1-R_{Y(X 1.1, \ldots ., X 1.5)}^{2}} \\
& =\sqrt{1-0,643} \\
& =0,357
\end{aligned}
$$

Hal tersebut berarti bahwa bahwa $X_{1.1}$ sampai $\mathrm{X}_{1.5}$ bersama-sama mempengaruhi keputusan menginap sebesar $0.643 \%$ dan sisanya sebesar $(0,357)^{2}=0,127 \times 100 \%=$ $12.7 \%$ dipengaruhi faktor lain yang tidak masuk ke dalam penelitian ini seperti service quality.

\subsection{Implikasi Hasil Temuan}

4.4.1 Temuan Penelitian Bersifat Teoritik

1. Berdasarkan hasil temuan penelitian penulis memperkuat konsep brand performance yang dikemukakan oleh Kevin L. Keller (2008:64) berupa dimensi brand performance yang terdiri dari Primary ingredients and supplementary features, Product reliability, durability, and serviceability, Service effectiveness, efficiency, and empathy, Style and design, dan Price. Dalam penelitian ini lebih dikembangkan lagi setiap dimensi.
2. Berdasarkan hasil temuan penelitian, penulis memodifikasi konsep keputusan pembelian yang dikemukakan oleh Kotler, Keller (2009:213), keputusan pembelian dapat dibagi menjadi enam, yaitu pemilihan produk, pemilihan merek, pemilihan saluran reservasi, waktu menginap, jumlah pemesanan kamar, metode pembayaran. Pada penelitian ini, modifikasi dari teori tersebut dengan mengansumsikan teori keputusan pembelian kepada keputusan menginap.

3. Brand performance memiliki pengaruh yang signifikan terhadap keputusan pembelian. Dengan demikian temuan penulis mengukuhkan berbagai premis yang dikemukakan oleh Menurut Zeithaml.

4.4.2 Temuan Penelitian Bersifat Empirik

1. Brand Performance The Jayakarta Bandung Boutique Suite Hotel \& Spa meliputi Primary ingredients and supplementary features; Product reliability, durability, and serviceability; Service effectiveness, efficiency, and empathy; Style and design dan Price.

2. Faktor keputusan menginap dapat dilihat dari enam faktor yaitu pemilihan produk, pemilihan merek, pemilihan saluran reservasi, waktu menginap, jumlah pemesanan kamar, dan metode pembayaran.

3. Terdapat satu sub variable dari brand performance yaitu prymary ingredients and supplementary features. Hal ini dikarenakan brand performance di The Jayakarta Bandung Boutique Suite Hotel \& Spa bertujuan untuk menanamkan bagaimana kinerja merek di benak tamu The Jayakarta Bandung Boutique Suite Hotel \& Spa yang menginap, menstimulus tamu untuk menginap dan melakukan aktivitas di The Jayakarta Bandung Boutique Suite Hotel \& Spa.

4. Faktor-faktor lain yang mempengaruhi keputusan menginap adalah service quality.

Berdasarkan temuan tersebut, maka diyakini hasil penelitian penulis mampu memberikan sumbangsih ilmiah bagi pengembangan ilmu manajemen pemasaran pariwisata, khususnya pemasaran jasa perhotelan dan juga sebagai masukan yang konstruktif dan inspiratif bagi para pengambil 
keputusan perusahaan The Jayakarta Bandung Boutique Suite Hotel \& Spa.

\section{KESIMPULAN}

Berdasarkan hasil penelitian yang telah dilakukan dengan menggunakan path analysis baik secara deskriptif dan verifikatif antara analisis keputusan menginap melalui brand performance pada The Jayakarta Bandung Boutique Suite Hotel \& Spa dapat diambil kesimpulan sebagai berikut:

1. Gambaran mengenai brand performance pada The Jayakarta Bandung Boutique Suite Hotel \& Spa mendapat penilaian yang baik dari tamu The Jayakarta Bandung Boutique Suite Hotel \& Spa. Penilaian tertinggi diperoleh oleh product reliability, durability, and serviceability sedangkan penilaian terendah diperoleh oleh service effectiveness, efficiency, and empathy seperti dijelaskan di bawah ini:

a. Secara keseluruhan brand performance pada The Jayakarta Bandung Boutique Suite Hotel \& Spa sudah baik, terutama product reliability, durability, and serviceability, dikarenakan para tamu telah merasakan produk yang telah ditawarkan oleh The Jayakarta Bandung Boutique Suite Hotel \& Spa, sehingga memberikan kesan yang baik di benak tamu.

b. Service effectiveness, efficiency, and empathy mendapatkan penilaian terendah. Walaupun secara signifikan berpengaruh terhadap keputusan menginap pada The Jayakarta Bandung Boutique Suite Hotel \& Spa, namun dirasa masih kurang dampaknya. Dimana tamu belum merasakan kesan yang baik dalam pemberian jasa The Jayakarta Bandung Boutique Suite Hotel \& Spa, terutama dalam menyikapi complain tamu yang tidak cukup memberikan kesan yang baik.

2. Gambaran mengenai tingkat keputusan menginap di The Jayakarta Bandung Boutique Suite Hotel \& Spa yang terdiri dari pemilihan produk, pemilihan merek, pemilihan saluran reservasi, waktu menginap, jumlah pemesanan kamar, metode pembayaran mendapat penilaian yang baik. Penilaian tertinggi adalah pemilihan merek. Hal ini dikarenakan citra perusahaan yang baik telah memberikan kenyamanan tersendiri bagi para tamu The Jayakarta Bandung Boutique Suite Hotel \& Spa.

3. Brand performance yang terdiri dari Primary ingredients and supplementary features, Product reliability, durability, and serviceability, Service effectiveness, efficiency, and empathy, Style and design, dan Price memberikan pengaruh terhadap keputusan menginap di The Jayakarta Bandung Boutique Suite Hotel \& Spa dengan tingkat pengaruh yang tinggi.

\section{Rekomendasi}

Konsep brand performance merupakan hal yang penting dalam suatu perusahaan, karena memiliki beberapa keuntungan diantaranya adalah mengurangi biaya pemasaran, memudahkan akses, menarik pelanggan baru, mempertahankan pelanggan, ekuitas merek, dan banyak lagi keuntungan yang bisa diperoleh melalui brand performance, dalam hal ini penulis mencoba memberikan saran seperti hal-hal berikut:

1. Secara keseluruhan Brand performance di The Jayakarta Bandung Boutique Suite Hotel \& Spa yang terdiri dari Primary ingredients and supplementary features; Product reliability, durability, and serviceability; Service effectiveness, efficiency, and empathy; Style and design; dan Price sudah dilakukan dengan baik dan terbukti mampu mempengaruhi keputusan menginap di The Jayakarta Bandung Boutique Suite Hotel \& Spa, namun hal terpenting yang harus diperhatikan oleh pihak manajemen The Jayakarta Bandung Boutique Suite Hotel \& Spa adalah mengenai kualitas pelayanan yang diberikan karyawan terhadap tamu. Pendekatan secara psikologikal yang harus diterapkan serta pelayanan yang menitikberatkan pada kebutuhan tamu, sehingga tamu bisa memberikan kepercayaan yang lebih kepada perusahaan dan memiliki keterikatan perasaan yang kuat dan menjadi tergantung kepada perusahaan. Hal tersebut sejalan dengan perolehan nilai yang terendah pada dimensi Service effectiveness, efficiency, and empathy. 
2. Keputusan menginap secara umum dapat dinilai cukup baik, namun ada yang harus ditingkatkan yaitu metode pembayaran dimana perusahaan harus memfokuskan kepada manfaat-manfaat yang lebih menarik dalam melakukan transaksi pembayaran, baik melalui uang tunai ataupun kartu kredit. Seperti adanya kerjasama antara pihak hotel dengan bank, sehingga adanya potongan harga ketika melakukan transaksi pembayaran, yang dapat menguntungkan tamu yang menginap.

Keterbatasan dalam penelitian ini yaitu peneliti hanya melakukan penelitian dengan survei terhadap tamu yang menginap di The Jayakarta Bandung Boutique Suite Hotel \& Spa. Sebagai bahan rekomendasi untuk peneliti selanjutnya di The Jayakarta Bandung Boutique Suite Hotel \& Spa, para peneliti selanjutnya dapat mengangkat masalah lain seperti pengaruh harga atau produk yang ditawarkan agar occupancy terus meningkat sesuai dengan target dan tamupun akan terus loyal dengan bebagai macam faktor penunjang seprti lokasi dan harga yang relative murah sehingga The Jayakarta Bandung Boutique Suite Hotel \& Spa akan semakin maju dan berkembang.

\section{DAFTAR PUSTAKA}

Asep Hermawan.2008. Penelitian Bisnis Paradigma Kuantitatif. Jakarta: PT. Grasindo.

Buchari Alma. 2007. Manajemen Pemasaran dan Pemasaran Jasa. Bandung : CV Alfabeta.

Fandy Tjiptono. 2005. Brand Management \& Strategy. Yogyakarta: Andi.

--------------. 2006. Manajemen Pemasaran Jasa. Solo: Andi.

---------------. Chandra. \& Adriana. 2008. Pemasaran Strategik. Yogyakarta: Penerbit Andi.

Kapferer, Jean-Noël. 2008. New Strategic Brand Management : Creating And Sustaining Brand Equity Long Term $4^{\text {th }}$ Edition. London and Philadelphia: Kogan Page Limited.

Keller, Kevin Lane. 2008. Strategic Brand Management: Building, Measuring, and Managing Brand Equity, $3^{\text {nd }}$ Edition, New Jersey: Prentice Hall.
Kotler, Philip \& Amstrong, Gary. 2008. Principles of Marketing $11^{\text {th }}$ Edition. New Jersey: Prentice Hall.

------------ \& Kevin L. Keller. 2009. Marketing Management $13^{\text {th }}$ Edition. New Jersey: Prentice Hall.

-------------- \& Amstrong, Gary, 2011. Principles of Marketing. New Jersey: Prentice Hall.

------------- \& Kevin Lane Keller. 2006. Marketing Management 12 th Edition Pearson Internasional Edition. New Jersey: Prentice Hall.

Hermawan Kertajaya \& Yuswohady. 2005. Attracting Tourists Traders Investors. Jakarta: PT Gramedia Pustaka Utama.

Husein, Umar. 2008. Metode Penelitian untuk Skripsi dan Tesis Bisnis. Jakarta: Rajagrafindo Persada.

Schiffman, Leon.G. dan Kanuk, Leslie, 2007. Consumer Behavior. Prentice Hall Internasional Inc.

Sekaran, Uma, (2006). Metodologi Penelitian Untuk Bisnis, Jakarta: Salemba Empat.

Sugiono. 2008. Metode Penelitian Bisnis. Bandung : Alfabeta.

Suharsimi Arikunto. 2008. Prosedur Penelitian Bisnis. Bandung: Alfabeta.

Sumarwan, Ujang. 2002. Perilaku Konsumen Teori dan Penerapan Dalam Pemasaran. Bogor: Ghalia Indonesia.

Ulber Silalahi, 2009. Metode Penelitian Sosial, PT Refika Aditama, Bandung.

Sumber Literatur Jurnal dan Website Harris, Fiona and de Chernatony, Leslie (2001). Corporate branding and corporate brand performance. European Journal of Marketing,

John W. O’Neill Anna S. Mattila Qu Xiao (2006). Hotel Guest Satisfaction and Brand Performance: The Effect of Franchising Strategy.

Zeithaml, (2006) Journal brand performance: quality assurance in hospitality \& tourism.

Journal of Product \& Brand Management (2008): Consumers tend to look for brands with greater perceived symbolic benefits when purchasing gifts.

Journal Marketing intelligence \& Planning(2008): Brands are actually positioned in the minds of consumers in 
terms of thei component memes, that is, their "genes of meaning".

Badan Pusat Statistik Jawa Barat

Departemen Kebudayaan dan Pariwisata

Indonesia

Dinas Pariwisata Kota Bandung

Dinas Perdagangan dan Perindustrian Kota

Bandung

www.disparbud.jabarprov.go.id

www.bps.go.id

www.tribun.com

www.kabarbisnis.com

www.dekominfo.go.id

www.personal.psu.edu

www.oro.open.ac.uk/1350/

http://lib.atmajaya.ac.id/default.aspx?tabID=6

$1 \&$ src $=k \& i d=158523$

http://eprints.upnjatim.ac.id/824/1/File_1.pd 
Indah Nur Agustiani, Anthony Barbo

Tourism and Hospitality Essentials (THE) Journal, Vol.II, No.2, 2012 - 386 